\title{
Effect of Seed Rate and Row Spacing on Tef (Eragrostis tef (Zucc.) Trotter) Production at Central Highlands of Ethiopia
}

\author{
Almaz Meseret Gezahegn*, Serkalem Tamiru \\ Ethiopian Institute of Agricultural Research, Debre Zeit Agricultural Research Center, Debre Zeit, Ethiopia \\ Email address: \\ almimeseret@gmail.com(A. M. Gezahegn) \\ ${ }^{*}$ Corresponding author \\ To cite this article: \\ Almaz Meseret Gezahegn, Serkalem Tamiru. Effect of Seed Rate and Row Spacing on Tef (Eragrostis tef (Zucc.) Trotter) Production at \\ Central Highlands of Ethiopia. Journal of Plant Sciences. Vol. 9, No. 3, 2021, pp. 71-76. doi: 10.11648/j.jps.20210903.11
}

Received: February 26, 2021; Accepted: April 16, 2021; Published: May 8, 2021

\begin{abstract}
Field experiments were conducted for three consecutive years (2012-2014) to determine optimum seed rate and row spacing for increasing productivity of tef at central highlands of Ethiopia. The experiment was designed in a randomized complete block design with a factorial combination of three levels of seed rates $(5,10$ and $15 \mathrm{~kg} / \mathrm{ha})$ and three rows spaces $(15$, $20,25 \mathrm{~cm}$ ) with three replications in a factorial arrangement. One satellite treatment of broadcasting of $25 \mathrm{~kg} / \mathrm{ha}$ seed rate was included. Results revealed that plant height and number of tillers were not significantly affected by a combination of seed rate and row spacing, however, panicle length was significantly affected by a combination of seed rate and row spacing. The lowest seed rate $(5 \mathrm{~kg} / \mathrm{ha})$ with $25 \mathrm{~cm}$ row spacing gave the highest panicle length. Yield and yield components of tef were also significantly affected by a combination of seed rate and row spacing at both locations. At both locations, $10 \mathrm{~kg} / \mathrm{ha}$ seed rate with $20 \mathrm{~cm}$ and broadcasted with $25 \mathrm{~kg} / \mathrm{ha}$ seed rate gave significantly higher grain yield, but were not significantly different from other treatments except $5 \mathrm{~kg}$ seed rate with $25 \mathrm{~cm}$ row spacing. The Partial budget analysis revealed that highest net benefit was recorded from $10 \mathrm{~kg} / \mathrm{ha}$ seed rate with $20 \mathrm{~cm}$ row spacing. Therefore, a seed rate of $10 \mathrm{~kg} / \mathrm{ha} \mathrm{with} 20 \mathrm{~cm}$ row spacing can be recommended for higher and economic yield of tef at central highlands of Ethiopia.
\end{abstract}

Keywords: Net Benefit, Row Spacing, Seed Rate, Tef, Yield

\section{Introduction}

Tef (Eragrostis tef (Zucc.) Trotter) is a staple food for the majority of Ethiopian population and adapted to a wide range of environment including situation which is unfavorable to the production of different crops [1]. The crop prefer to grow by Ethiopian farmers due to multiple advantages such as low risk crop, low postharvest management cost, high market value, and straw of tef is the best feed for animal feed as compared to different cereal crops, [2]. Tef straw, other than being the foremost acknowledged feed for cattle, it is additionally utilized to strengthen mud and mortar the dividers of tukuls and nearby grain capacity offices called gottera [3, 4]. Currently, the crop is getting worldwide consideration among money crops and has been drawing in an send out advertise owing to its wholesome and healthrelated benefits [5], particularly due to its gluten free property $[6,7]$.

Tef has the significance value in terms of both production and consumption in Ethiopia. It positions first in area coverage and second in total annual production following to maize, and positions the bottommost yield compared with other cereals grown in Ethiopia [8, 9]. Tef covers for about $22.6 \%$ of the total area and $16 \%$ of the total crop production of the main cereals produced in Ethiopia [8]. Tef production and request has been expanding from year to year in both country and urban ranges of Ethiopia. In spite of the abovementioned importance and huge area coverage, its productivity is very low with a national average yield of $1.71 \mathrm{t} / \mathrm{ha}$ [8]. The low productivity of tef in Ethiopia is largely attributed to its susceptibility to lodging, its small seed size, moisture stresses [10], and poor agronomic management practices, such as lack of appropriate sowing method and optimum seeding rate [11].

Seed rate is one of the significant factors in attaining optimum level of plant density and has substantial effects on growth and yield of the crops. It also highly affects crop productivity when combined with planting method. In 
Ethiopia, there is inconsistency in using improved agronomic practices like seeding rate and planting methods and results in low yield of tef [12]. The most common method of sowing is broadcasting at a rate of $25-50 \mathrm{~kg} / \mathrm{ha}$ which is conventional and greatly reduces the amount of tef grain yield due to higher competition for resources and causes lodging [4]. Alternatively, row planting keeps uniform population per unit area and offers easy accessibility for completing management practices though needs extra time, energy, and cost [13]. Similarly, using of optimum seed rate allows boosting production and productivity of tef through reducing of lodging percent [14]. However, in Ethiopia particularly in study area, farmers practice broad casting methods of sowing tef with higher seed rate. Therefore, the study was conducted to determine the optimum seed rate and appropriate row spacing for increasing productivity of tef in central highlands of Ethiopia.

\section{Materials and Methods}

\subsection{Description of the Study Area}

The experiments were conducted at Debre Zeit Agricultural Research Center (DZARC) station and Ude farmer field during 2012-2014 cropping season under rainfed condition. Debre Zeit Agricultural Research Center and Ude are located in East Shewa Zone of Oromia Regional State. Debre Zeit agricultural research center is located an altitude of $1,900 \mathrm{~m}$ above sea level and $8^{\circ} 44^{\prime} \mathrm{N}$ latitude and $38^{\circ} 58^{\prime}$ E longitude. While Ude is located at $9^{\circ} 5^{\prime} 52.8^{\prime \prime} \mathrm{N}$ latitude and $36^{\circ} 58^{\prime} 37.2^{\prime \prime} \mathrm{E}$ longitude with an altitude of 1970 meter above sea level. Those areas are typical of the rain-fed tef-growing regions of Ethiopia with average annual rainfall of $912 \mathrm{~mm}$ and $826 \mathrm{~mm}$ at DARC and Ude, respectively. The dominant soil types of the areas are heavy Vertisol. Monthly total rainfall and average minimum and maximum temperature of DZARC and Ude over the 3-year study periods are presented in Figures 1 and 2, respectively.

\subsection{Experimental Design and Treatments}

Table 1. Treatment combinations.

\begin{tabular}{ll}
\hline Treatment no. & Treatment combinations \\
\hline 1 & $5 \mathrm{~kg} / \mathrm{ha} \times$ Row space $15 \mathrm{~cm}$ \\
2 & $5 \mathrm{~kg} / \mathrm{ha} \times$ Row space $20 \mathrm{~cm}$ \\
3 & $5 \mathrm{~kg} / \mathrm{ha} \times$ Row space $25 \mathrm{~cm}$ \\
4 & $10 \mathrm{~kg} / \mathrm{ha} \times$ Row space $15 \mathrm{~cm}$ \\
5 & $10 \mathrm{~kg} / \mathrm{ha} \times$ Row space $20 \mathrm{~cm}$ \\
6 & $10 \mathrm{~kg} / \mathrm{ha}$ x Row space $25 \mathrm{~cm}$ \\
7 & $15 \mathrm{~kg} / \mathrm{ha}$ x Row space $15 \mathrm{~cm}$ \\
8 & $15 \mathrm{~kg} / \mathrm{ha}$ x Row space $20 \mathrm{~cm}$ \\
9 & $15 \mathrm{~kg} / \mathrm{ha}$ x Row space $25 \mathrm{~cm}$ \\
10 & $25 \mathrm{~kg} / \mathrm{ha}$ at broad casting \\
\hline
\end{tabular}

The experiment was designed in a randomized complete block design with three replications. The treatment comprised with a factorial arrangement of three levels of seed rates $(5,10$ and $15 \mathrm{~kg} / \mathrm{ha})$ and three rows spacing (15,
$20,25 \mathrm{~cm})$. One additional plot of broadcast of tef seed at 25 $\mathrm{kg} / \mathrm{ha}$ seed rate for each replication was considered as a standard check. The treatment combination is presented in Table 1. The plot size of $4 \mathrm{~m} \times 5 \mathrm{~m}\left(20 \mathrm{~m}^{2}\right)$ was used. The spacing between plots and blocks were $0.5 \mathrm{~m}$ and $1 \mathrm{~m}$, respectively.

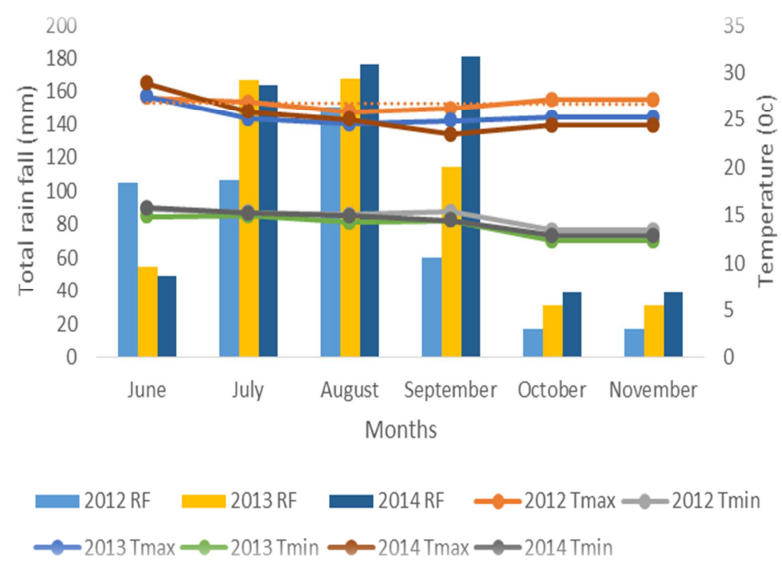

Figure 1. Total rainfall, minimum and maximum Temperature for the cropping season during 2012-2014 at Debre Zeit.

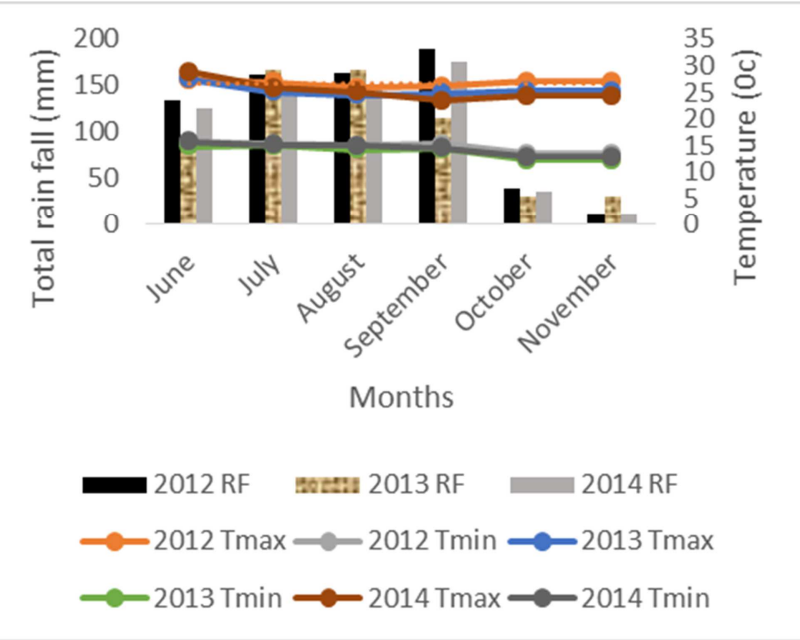

Figure 2. Total rainfall, minimum and maximum Temperature for the cropping season during 2012-2014 at Ude.

\subsection{Crop Management and Data Collection}

The experimental site was ploughed by tractor to a fine till at DZARC and by oxen 4 times before final preparation of seed beds at Ude. Urea $(46 \% \mathrm{~N})$ at a rate of $100 \mathrm{~kg} / \mathrm{ha}$ and DAP $\left(18 \% \mathrm{~N}, 48 \% \mathrm{P}_{2} \mathrm{O}_{5}\right)$ fertilizer at rate of $100 \mathrm{~kg} / \mathrm{ha}$ were used as a source of nitrogen, and phosphorus, respectively. Full dose of DAP was applied at planting, while urea fertilizer was applied in two equal splits, the first portion 15 days after planting and the remaining amount being top dressed at tillering stage. Other agronomic practices were applied based on local research recommendations. The first weeding was done 30-35 days after planting and the second weeding was carried out a month after the first weeding. 
Plant height was measured from the surface ground to the tip of the panicle at maturity time. Panicle length was measured the node (the first panicle branch started) to the tip of the panicle. Number of tillers per plant was determined by counting the number of additional plants growing from the main stem. The samples for the above parameters were taken from 10 randomly taken plants. Above ground biomass was determined by taking the total weight of the harvest including the grains from each net plot area. Straw yield was measured by subtracting grain yield per net plot from the total above ground biomass. Grain yield ( $\mathrm{kg} / \mathrm{ha})$ was measured after threshing the grains harvested from each net plot. Harvest index was calculated by the ratio of grain yield to above ground biomass.

\subsection{Economic Analysis}

To compare the economic feasibilities of different treatments, partial budget analysis and Marginal rate of return were done as described by CIMMYT [15]. The average grain and straw yield was adjusted downwards by $10 \%$ to reflect the difference between the experimental yield and the expected yield of farmers from the same treatment. The costs that vary were calculated by adding costs of seed and other costs were constant for each treatment. The mean market price of tef grain (40 Birr $/ \mathrm{kg}$ ) and straw cost (3Birr $/ \mathrm{kg})$ were used.

\subsection{Statistical Analysis}

The data were subjected to combined analysis of variance (ANOVA) over years after confirmation of homogeneity of error variance using SAS software program. Separate analyses were conducted for each location because of heterogeneity of error variance. The means were compared by list significant difference (LSD) method at 0.05 probability level.

\section{Result and Discussion}

\subsection{Growth Parameters}

The result indicated that seed rate and row spacing had not significant effect $(p>0.05)$ on plant height and number of productive tillers of tef at both locations (Table 2). However, panicle length of tef was significantly affected by $(p>0.05)$ combination of seed rate and row spacing. Panicle length is one of the major yield attributes of tef that is positively correlated with grain yield. The highest panicle length was obtained when the crop was planted at $5 \mathrm{~kg} / \mathrm{ha}$ seed rate with $15 \mathrm{~cm}$ row spacing, but was not significantly different ( $\mathrm{P}>0.05$ ) from $5 \mathrm{~kg}$ seed rate by 20 and $25 \mathrm{~cm}$ row spacing, 10 $\mathrm{kg}$ seed rate by $20 \mathrm{~cm}$ row spacing and $15 \mathrm{~kg}$ seed rate by 15 $\mathrm{cm}$ row spacing at Ude. At Debre Zeit, the highest panicle length was obtained when tef was planted at seed rate of $5 \mathrm{~cm}$ with 25 and 20 row spacing, but were not significantly different $(\mathrm{P}>0.05)$ from other seed rate planted in row. In contrast, the lowest panicle length was obtained when the crop was broadcasts at the rate of $25 \mathrm{~kg} / \mathrm{ha}$ at both locations. The increment of panicle length in the case of row space increment as well as decreasing seed rate might be resulted due to extra space given for the crop to utilize additional growth resources by reducing competition between plants. The lower panicle length at higher seed rate might be due to the higher intraspecific competition between plants for the resources. Plants grown with a lower plant density had more area of land around them to utilize more resources such as nutrient, water and solar radiation on individual plant basis than those established at higher plant density because of competition. This result is in agreement with Kitata et al. [16] and Sahle et al. [17], who reported higher panicle length in lower seed rate and vise versa. Reda et al. [18] also reported that the performance of the individual tef plant grown under low plant density was better as compared to the tef plant with lower plant density.

Table 2. Effect of seed rate and row spacing on growth parameters of tef at Ude and Debre Zeit.

\begin{tabular}{|c|c|c|c|c|c|c|}
\hline \multirow{2}{*}{ Treatments } & \multicolumn{3}{|l|}{ Ude } & \multicolumn{3}{|c|}{ Debre Zeit } \\
\hline & PH (cm) & NT & PL(cm) & PH (cm) & NT & PL(cm) \\
\hline $5 \mathrm{~kg} / \mathrm{ha} \times$ Row space $15 \mathrm{~cm}$ & 93.17 & 3.7667 & 45.44abcd & 106.67 & 4.73 & $37.67 \mathrm{ab}$ \\
\hline $5 \mathrm{~kg} / \mathrm{ha}$ x Row space $20 \mathrm{~cm}$ & 103.00 & 3.2333 & 45.30abcd & 107.00 & 5.167 & $39.73 a$ \\
\hline $5 \mathrm{~kg} / \mathrm{ha} \times$ Row space $25 \mathrm{~cm}$ & 108.67 & 3.1667 & $48.79 \mathrm{a}$ & 111.17 & 4.77 & $40.53 \mathrm{a}$ \\
\hline $10 \mathrm{~kg} / \mathrm{ha} \times \mathrm{x}$ Row space $15 \mathrm{~cm}$ & 98.00 & 3.3667 & $43.59 \mathrm{~cd}$ & 118.17 & 3.70 & $35.93 \mathrm{ab}$ \\
\hline $10 \mathrm{~kg} / \mathrm{ha} \times$ Row space $20 \mathrm{~cm}$ & 95.33 & 3.7333 & $47.83 \mathrm{ab}$ & 112.67 & 5.57 & $36.13 \mathrm{ab}$ \\
\hline $10 \mathrm{~kg} / \mathrm{ha} \times$ Row space $25 \mathrm{~cm}$ & 95.50 & 3.7667 & $42.50 \mathrm{~cd}$ & 110.00 & 4.27 & $36.48 \mathrm{ab}$ \\
\hline $15 \mathrm{~kg} / \mathrm{ha} \times \mathrm{x}$ Row space $20 \mathrm{~cm}$ & 96.50 & 3.4333 & $44.83 \mathrm{bcd}$ & 106.67 & 4.82 & $36.80 \mathrm{ab}$ \\
\hline $15 \mathrm{~kg} / \mathrm{ha} \times$ Row space $25 \mathrm{~cm}$ & 97.50 & 3.1667 & $43.52 \mathrm{~cd}$ & 110.17 & 4.73 & $36.80 \mathrm{ab}$ \\
\hline $25 \mathrm{~kg} / \mathrm{ha}$ at broad casting & 114.33 & 2.9667 & $42.23 \mathrm{~d}$ & 116.00 & 4.33 & $34.40 \mathrm{~b}$ \\
\hline $\operatorname{LSD}(\mathrm{P}>0.05)$ & ns & ns & 3.89 & ns & ns & 4.7 \\
\hline $\mathrm{CV}$ & 25.25 & 22.91 & 7.44 & 17.7 & 10.2 & 15.2 \\
\hline
\end{tabular}

$\mathrm{PH}=$ plant height, $\mathrm{NT}=$ number of productive tillers, $\mathrm{PL}=$ panicle length.

\subsection{Yield and Yield Components}

The combination of seed rate and row spacing had a significant effect $(\mathrm{P}<0.05)$ on biomass yield, and grain yield at both locations and on straw yield at Debre Zeit. However, harvest index of tef was not significantly affected $(\mathrm{P}>0.05)$ by combination of seed rate and row spacing. At Ude, the highest biomass yield $(5916.7 \mathrm{~kg} / \mathrm{ha})$ was obtained in the control plot, which was broadcasted at $25 \mathrm{~kg} / \mathrm{ha}$ seed rate, but was not significantly different $(\mathrm{P}>0.05)$ from other treatments 
except $5 \mathrm{~kg} /$ ha seed rate with 20 and $25 \mathrm{~cm}$ row spacing. On the other hand, at Deber zeit the highest biomass yield $(9333 \mathrm{~kg} / \mathrm{ha})$ and straw yield $(7634 \mathrm{~kg} / \mathrm{ha})$ were obtained when tef was planted at $15 \mathrm{~kg} / \mathrm{ha}$ seed rate and $25 \mathrm{~cm}$ row spacing. In contrast, the lowest biomass yield and straw yield were obtained when tef was planted at a seed rate of $5 \mathrm{~kg} / \mathrm{ha}$ with $25 \mathrm{~cm}$ row spacing at both locations and at Debre zeit, respectively. This implies that the biomass yield increases as the seed rate or planting density increase. This is due to the fact that the seed rate increase, the number of plant establishment, the plant height and number of plants per unit area increases, which substantially increases the biomass of the plant. The result is in line with Reda et al. [18] and Lakew and Berhanu [19] who reported the highest biomass yield of tef at higher seed rate.

The highest grain yield was obtained at seed rate of 10 $\mathrm{kg} / \mathrm{ha}$ with $20 \mathrm{~cm}$ and $25 \mathrm{~cm}$ row spacing, $15 \mathrm{~kg} / \mathrm{ha}$ with 15 $\mathrm{cm}$ and control plot or broadcasted at $25 \mathrm{~kg} / \mathrm{ha}$ seed rate
$(1525.4 \mathrm{~kg} / \mathrm{ha}, 1417.7 \mathrm{~kg} / \mathrm{ha}, 1407.1 \mathrm{~kg} / \mathrm{ha}$ and $1523.5 \mathrm{~kg} / \mathrm{ha}$, respectively) at Ude. Similarly, at Debre Zeit, seed rate of 10 $\mathrm{kg} / \mathrm{ha}$ with 15 and $20 \mathrm{~cm}$ row spacing and broadcasting tef with $25 \mathrm{~kg} / \mathrm{ha}$ seed rate were gave highest grain yield (1820 $\mathrm{kg} / \mathrm{ha}, 1875 / \mathrm{kg} / \mathrm{ha}$ and $1833 \mathrm{~kg} / \mathrm{ha}$, respectively), but were not significantly different from other treatments except 5 $\mathrm{kg} / \mathrm{ha}$ seed rate with $25 \mathrm{~cm}$ row spacing. At both locations, the lowest grain yield was obtained at $5 \mathrm{~kg} / \mathrm{ha}$ seed rate with $25 \mathrm{~cm}$ row spacing. The result indicated that there was a slightly increment of grain yield as the seed rate increased. This might be due to number of plants per meter square is the main determinants of yield. Similarly, Lakew and Birhanu [19] reported that $15 \mathrm{~kg}$ seed rate gave higher grain yield of tef than 10 and $5 \mathrm{~kg} / \mathrm{ha}$. Further the result showed that row spacing didn't increase grain as well as biomass yield of tef over broadcast. In contrary to this result, Mihretie et al. [20] reported that row planting gave greater $(30 \%)$ grain yield of tef than broadcasting.

Table 3. Effect of seed rate and row spacing on yield and yield component of tef at Ude and Debre Zeit.

\begin{tabular}{|c|c|c|c|c|c|c|c|c|}
\hline \multirow{2}{*}{ Treatments } & \multicolumn{4}{|l|}{ Ude } & \multicolumn{4}{|l|}{ Debre Zeit } \\
\hline & SY (kg/ha) & BY (kg/ha) & GY (kg/ha) & HI (\%) & SY (kg/ha) & BY (kg/ha) & GY (kg/ha) & HI (\%) \\
\hline $5 \mathrm{~kg} / \mathrm{ha} \times$ Row space $15 \mathrm{~cm}$ & 3778.5 & $5083 \mathrm{abc}$ & $1305 \mathrm{ab}$ & 0.26 & $4694 b$ & $6083 \mathrm{ab}$ & $1389 \mathrm{ab}$ & 0.23 \\
\hline $5 \mathrm{~kg} / \mathrm{ha} \times$ Row space $20 \mathrm{~cm}$ & 3486.4 & $4833 \mathrm{bc}$ & $1347 \mathrm{ab}$ & 0.28 & $5350 \mathrm{ab}$ & $6875 \mathrm{ab}$ & $1525 \mathrm{ab}$ & 0.26 \\
\hline $5 \mathrm{~kg} / \mathrm{ha} \times$ Row space $25 \mathrm{~cm}$ & 3651.3 & $4792 c$ & $1140 \mathrm{~b}$ & 0.24 & $4729 b$ & $5833 b$ & $1105 b$ & 0.18 \\
\hline $10 \mathrm{~kg} / \mathrm{ha} \times$ Row space $15 \mathrm{~cm}$ & 4058.8 & $5417 \mathrm{abc}$ & $1358 \mathrm{ab}$ & 0.25 & $7181 \mathrm{ab}$ & $9000 \mathrm{ab}$ & $1820 \mathrm{a}$ & 0.19 \\
\hline $10 \mathrm{~kg} / \mathrm{ha} \times$ Row space $20 \mathrm{~cm}$ & 4349.6 & $5875 \mathrm{ab}$ & $1525 \mathrm{a}$ & 0.26 & $7083 \mathrm{ab}$ & $8958 \mathrm{ab}$ & $1875 \mathrm{a}$ & 0.21 \\
\hline $10 \mathrm{~kg} / \mathrm{ha} \times$ Row space $25 \mathrm{~cm}$ & 3957.3 & $5375 \mathrm{abc}$ & $1418 \mathrm{a}$ & 0.26 & $6401 \mathrm{ab}$ & $7958 \mathrm{ab}$ & $1557 \mathrm{ab}$ & 0.18 \\
\hline $15 \mathrm{~kg} / \mathrm{ha} \times$ Row space $15 \mathrm{~cm}$ & 4134.6 & $5542 \mathrm{abc}$ & $1407 \mathrm{a}$ & 0.25 & $7391 \mathrm{ab}$ & $9125 \mathrm{ab}$ & $1735 \mathrm{ab}$ & 0.19 \\
\hline $15 \mathrm{~kg} / \mathrm{ha} \times$ Row space $20 \mathrm{~cm}$ & 4221.2 & $5333 \mathrm{abc}$ & $1112 b$ & 0.21 & $7373 \mathrm{ab}$ & $8833 \mathrm{ab}$ & $1460 \mathrm{ab}$ & 0.16 \\
\hline $15 \mathrm{~kg} / \mathrm{ha} \times$ Row space $25 \mathrm{~cm}$ & 3866.5 & $5167 \mathrm{abc}$ & $1300 \mathrm{ab}$ & 0.25 & $7634 a$ & $9333 a$ & $1700 \mathrm{ab}$ & 0.18 \\
\hline $25 \mathrm{~kg} / \mathrm{ha}$ at broad casting & 4393.2 & $5917 \mathrm{a}$ & $1523 a$ & 0.26 & 6918ab & $8750 \mathrm{ab}$ & $1833 a$ & 0.22 \\
\hline $\operatorname{LSD}(\mathrm{P}>0.05)$ & $\mathrm{ns}$ & 1048 & 265.09 & ns & 2712 & 3345 & 667.9 & $\mathrm{~ns}$ \\
\hline $\mathrm{CV}$ & 19.86 & 16.93 & 17.00 & 15.31 & $4694 b$ & $6083 \mathrm{ab}$ & $1389.4 \mathrm{ab}$ & 0.23 \\
\hline
\end{tabular}

$\mathrm{SY}=$ straw yield, $\mathrm{BY}=$ biomass yield, $\mathrm{GY}=$ grain yield, $\mathrm{HI}=$ harvest index.

\subsection{Economic Analysis}

Partial budget analysis at Ude showed that the highest net benefit $(66225 \mathrm{~kg} / \mathrm{ha})$ was obtained when tef was seeded at a rate of $10 \mathrm{~kg} / \mathrm{ha}$ with $20 \mathrm{~cm}$ row spacing, followed by broadcasted $25 \mathrm{~kg} / \mathrm{ha}$ seed rate (Table 4). Similarly, at Debre Zeit, the highest net benefit was obtained at $10 \mathrm{~kg} / \mathrm{ha}$ seed rate with $20 \mathrm{~cm}$ row spacing followed by $10 \mathrm{~kg} / \mathrm{ha}$ seed rate with $15 \mathrm{~cm}$ row spacing (Table 5). This finding is in line with Lakew and Brehanu [19] who stated that an combination of $15 \mathrm{~kg} \mathrm{ha}^{-1}$ seed rate with $20 \mathrm{~cm}$ row spacing gave higher net benefit than that of broadcasting with higher seed rate. Abebe and Abebe [21] also reported that tef sown with $5 \mathrm{~kg} / \mathrm{ha}$ is economically beneficial for farmers compared to broadcasting with higher seed rate.

Table 4. Partial budget analysis for seed rate and row spacing at Ude.

\begin{tabular}{|c|c|c|c|c|c|c|c|}
\hline Treatment & GY (kg/ha) & SY (kg/ha) & Adj.GY (kg/ha) & Adj.SY (kg/ha) & GB (ETB) & TVC (ETB) & NB (ETB) \\
\hline $5 \mathrm{~kg} / \mathrm{ha} \times$ Row space $15 \mathrm{~cm}$ & 1305 & 3779 & 1174 & 3401 & 57175 & 200 & 56975 \\
\hline $5 \mathrm{~kg} / \mathrm{ha} \times$ Row space $20 \mathrm{~cm}$ & 1347 & 3486 & 1212 & 3138 & 57902 & 200 & 57702 \\
\hline $5 \mathrm{~kg} / \mathrm{ha} \times$ Row space $25 \mathrm{~cm}$ & 1140 & 3651 & 1026 & 3286 & 50913 & 200 & 50713 \\
\hline $10 \mathrm{~kg} / \mathrm{ha} \times$ Row space $15 \mathrm{~cm}$ & 1358 & 4059 & 1222 & 3653 & 59843 & 400 & 59443 \\
\hline $10 \mathrm{~kg} / \mathrm{ha} \times$ Row space $20 \mathrm{~cm}$ & 1525 & 4350 & 1373 & 3915 & 66658 & 400 & 66258 \\
\hline $10 \mathrm{~kg} / \mathrm{ha} \times$ Row space $25 \mathrm{~cm}$ & 1418 & 3957 & 1276 & 3562 & 61722 & 400 & 61322 \\
\hline $15 \mathrm{~kg} / \mathrm{ha} \times$ Row space $15 \mathrm{~cm}$ & 1407 & 4135 & 1266 & 3721 & 61819 & 600 & 61219 \\
\hline $15 \mathrm{~kg} / \mathrm{ha} \times$ Row space $20 \mathrm{~cm}$ & 1112 & 4221 & 1001 & 3799 & 51433 & 600 & 50833 \\
\hline $15 \mathrm{~kg} / \mathrm{ha}$ x Row space $25 \mathrm{~cm}$ & 1300 & 3867 & 1170 & 3480 & 57247 & 600 & 56647 \\
\hline $25 \mathrm{~kg} / \mathrm{ha}$ at broad casting & 1524 & 4393 & 1371 & 3954 & 66708 & 1000 & 65708 \\
\hline
\end{tabular}

${ }^{*} \mathrm{GY}=$ grain yield, $\mathrm{SY}=$ straw yield, Adj. $\mathrm{GY}=$ Adjusted grain yield, Adj. $\mathrm{SY}=$ adjusted straw yield, $\mathrm{GB}=$ gross benefit, $\mathrm{TVC}=$ total variable cost, $\mathrm{NB}=$ net benefit, $\mathrm{ETB}=$ Ethiopian Birr 
Table 5. Partial budget analysis for seed rate and row spacing at Debre Zeit.

\begin{tabular}{|c|c|c|c|c|c|c|c|}
\hline Treatment & GY (kg/ha) & SY (kg/ha) & Adj.GY (kg/ha) & Adj.SY (kg/ha) & GB (ETB) & TVC (ETB) & NB (ETB) \\
\hline $5 \mathrm{~kg} / \mathrm{ha}$ x Row space $15 \mathrm{~cm}$ & 1389 & 4694 & 1250 & 4225 & 62692 & 200 & 62492 \\
\hline $5 \mathrm{~kg} / \mathrm{ha} \times$ Row space $20 \mathrm{~cm}$ & 1525 & 5350 & 1373 & 4815 & 69359 & 200 & 69159 \\
\hline $5 \mathrm{~kg} / \mathrm{ha} \times$ Row space $25 \mathrm{~cm}$ & 1105 & 4729 & 994 & 4256 & 52534 & 200 & 52334 \\
\hline $10 \mathrm{~kg} / \mathrm{ha} \times$ Row space $20 \mathrm{~cm}$ & 1875 & 7083 & 1688 & 6375 & 86639 & 400 & 86239 \\
\hline $10 \mathrm{~kg} / \mathrm{ha} \times$ Row space $25 \mathrm{~cm}$ & 1557 & 6401 & 1402 & 5761 & 73346 & 400 & 72946 \\
\hline $15 \mathrm{~kg} / \mathrm{ha} \times$ Row space $15 \mathrm{~cm}$ & 1735 & 7391 & 1561 & 6652 & 82401 & 600 & 81801 \\
\hline $15 \mathrm{~kg} / \mathrm{ha} \times$ Row space $25 \mathrm{~cm}$ & 1700 & 7633 & 1530 & 6870 & 81802 & 600 & 81202 \\
\hline $25 \mathrm{~kg} / \mathrm{ha}$ at broad casting & 1833 & 6918 & 1649 & 6226 & 84647 & 1000 & 83647 \\
\hline
\end{tabular}

$\mathrm{GY}=$ grain yield, $\mathrm{SY}=$ straw yield, Adj. GY= Adjusted grain yield, Adj.SY=adjusted straw yield, GB= gross benefit, $\mathrm{TVC}=$ total variable cost, $\mathrm{NB}=$ net benefit, $\mathrm{ETB}=$ Ethiopian Birr

\section{Conclusions}

Based on the study, a combination of seed rate and row spacing had a significant effect on grain and biomass yield of tef at Ude and Debre zeit. The highest grain yield of tef were obtained at $10 \mathrm{~kg} / \mathrm{ha}$ seed rate with 20 and $25 \mathrm{~cm}$ row spacing, but was not significantly different from $25 \mathrm{~kg}$ of seed rate with broadcasting. Partial budget analysis showed that, at both locations, $10 \mathrm{~kg} / \mathrm{ha}$ seed rate with $20 \mathrm{~cm}$ row spacing gave the highest net benefit. Therefore, based on highest grain yield and economic advantage, $10 \mathrm{~kg} / \mathrm{ha}$ seed rate with $20 \mathrm{~cm}$ row spacing is recommended for the study areas.

\section{References}

[1] Hailu, T., Seyfu, K. (2001). Production and Importance of Tef in Ethiopia Agriculture. In: Tef Research and Development. Proceedings of the International Workshop on Tef Genetics and Improvement, DebreZeit, Ethiopia, Haramaya, Ethiopia, pp. 3-7.

[2] Ketema, S. (1991) Germplasm Evaluation and Breeding Work on Tef in Ethiopia, Cambridge University Press, Cambridge, UK.

[3] Ketema, S. (1997). Tef (Eragrostis tef) promoting the conservation and use of underutilized and neglected crops. Biodiversity Institute, Addis Ababa, Ethiopa. pp. 24.

[4] Tesfahun, W. (2018). Tef Yield Response to NPS Fertilizer and Methods of Sowing in East Shewa, Ethiopia. Journal of Agricultural Sciences, 13 (2): 162-173.

[5] Provost, C., \& Jobson, E. (2014). Move over quinoa, Ethiopia's teff poised to be next big super grain. The Guardian.

[6] Fikadu, A., Wedu, T. D., \& Derseh, E. (2019). Review on Economics of Teff in Ethiopia. Open Access Biostatistics \& Bioinformatics, 2, 1-8. OABB. 000539. 2019.

[7] Spaenij-Dekking, L., Kooy-Winkelaar, Y., \& Koning, F. (2005, Oct 20). The Ethiopian cereal tef in celiac disease. New England Journal of Medicine, 353 (16), 1748-1749.

[8] CSA (Central Statistic Authority), (2019). Agricultural Sample Survey: Report on Area and Production of Major Crops (Private Peasant Holdings "meher" Season), vol. I, CSA, Addis Abeba, Ethiopia.
[9] Assefa, K., Chanyalew, S. and Tadele, Z. (2017). Tef, Eragrostis tef (Zucc.) Trotter. Millets and Sorghum, In: Biology and Genetic Improvement, pp. 226-266.

[10] Seyfu, K. (1997). Tef (Eragrostis tef (Zucc.) Trotter: Promoting the conservation and use of underutilized and neglected crops (Vol. 12). Gatersleben/International Plant Genetic Resources Institute.

[11] Berhe, T. (2008). "Increasing Productivity of Tef, Eragrostis Tef (Zucc.) Trotter: New Approaches with Dramatic Results (Unpublished Report)" Addis Ababa, Ethiopia, 2008.

[12] Arefaine, A., Adhanom, D., \& Tekeste, N. (2020). Response of Teff (Eragrostis tef (Zucc) Trotter) to Seeding Rate and Methods of Sowing on Yield and Yield Attributes in a Subhumid Environment, Northern Ethiopia. International Journal of Agronomy, 2020.

[13] Chandrasekaran, B., Annadurai, K., \& Somasundaram, E. (2010). A textbook of agronomy. New Age International Limited.

[14] ATA (Agricultural Transformation Agency), (2012). Innovations to help our country grow. (http://www.ata.gov.et/programs/value-chain-programs/tef/) (Accessed on March 2013).

[15] CIMMYT (International Maize and Wheat Improvement center, (1988). An Economic Training Manual: from agronomic data recordation. CYMMT. Mexico. $79 \mathrm{pp}$.

[16] Kitata, S., Abera, T., \& Nandeshwar, B. Effects of Seed Rate and Row Spacing on Yield and Yield Components of Teff (Eragrostis tef [Zucc.] Trotter.) in Kiltu Kara Distirct of Western Ethiopia. International Journal of Plant \& Soil Science, 32 (15), 8-23.

[17] Sahle, S., \& Altaye, T. (2016). Effects of sowing methods and seed rates on yield components and yield of tef in soro woreda, hadya zone, southern Ethiopia. Journal of Natural Sciences, 6 (19).

[18] Reda, A., Dechassa, N., \& Assefa, K. (2018). Evaluation of seed rates and sowing methods on growth, yield and yield attributes of tef [Eragrostis tef (Zucc.) Trotter] in Ada District, East Shewa, Ethiopia. American-Eurasian J. Agric. \& Environ. Sci, 18 (1), 34-49.

[19] Lakew, A., \& Berhanu, T. (2019). Determination of seeding rate and inter row spacing on the yield of tef (Eragrostis tef Zucc. Trotter) in the dryland areas of Wag Lasta, North Eastern Amhara, Ethiopia. Archives of Agriculture and Environmental Science, 4 (1), 69-74 
[20] Mihretie, F., Tsunekawa, A., Bitew, Y., Chakelie, G., Derebe, B., Getahun, W.,... \& Asfaw, M. (2020). Teff [Eragrostis tef (Zucc.)] rainfed yield response to planting method, seeding density, and row spacing. Agronomy Journal, 113, 1, 111-122.
[21] Abebe, B., \& Abebe, A. (2016). Effect of Seed Rate on Yield and Yield Components of Tef [(Eragrostic tef) Trotter] at Shebedino, Southern Ethiopia. Journal of Natural Sciences Research. www.iiste.org, 6 (21). 